\title{
The consultant's role in continuing medical education of general practitioners: the case of rheumatology
}

\author{
ELIZABETH M BADLEY, JENNIFER LEE
}

\begin{abstract}
Consultant rheumatologists were surveyed by questionnaire about their contribution to the continuing education of general practitioners, and 84\% (203/243) replied. Altogether 157 respondents had participated in some form of teaching, 147 in collective teaching sessions such as lectures and 99 in the teaching of small groups. Arthritis comprised $44 \%$ of the rheumatological topics taught; there was a noticeable lack of teaching on problems commonly encountered in general practice, such as soft tissue rheumatism and injury and back pain, and on clinical skills including examination and injection of joints. Eighty eight respondents made comments and suggestions. The favoured educational strategies were small group teaching, apprenticeship schemes, and interchange between general practitioners and consultants about shared cases. This contrasts with what was typically done-namely, formal lectures on rheumatoid arthritis in postgraduate medical centres. These findings raise questions about the continuing education of consultants themselves as well as about the consultants' role in teaching others.
\end{abstract}

\section{Introduction}

"With the attainment of the College's [Royal College of General Practitioners'] intermediate goals in relation to early postgraduate training for general practice . . . it is appropriate that increasing attention should now be directed to the continuing education of the established practitioner."'

Continuing education has been defined as "the process by which doctors keep up to date with advances in medicine and improve their practice." With the increasing emphasis on community rather than institutional care there is also the need to adapt to changing relations between various branches of the health professions that have a role in health care. ${ }^{3}$ Only recently has interest in the continuing education of general practitioners featured to any great extent in published work, and it is perhaps not surprising that such papers as there are have tended to focus on the general practitioners and their opinions. ${ }^{47}$ Various other parties, however, are concerned with this educational process: the Royal College of General Practitioners in setting an example, the pharmaceutical industry, and specialists. Specialists may be seen as an educational resource with regard to changes in the content of a specialty and as a participant in education about changing relations.

Rheumatic complaints are one of the commonest reasons for

\footnotetext{
Arthritis and Rheumatism Council Epidemiology Research Unit, Manchester University Medical School, Manchester M13 9PT

ELIZABETH M BADLEY, MSC, DPHIL, deputy director JENNIFER LEE, BSC, research assistant
}

consultation in general practice. It is estimated that each year $15 \%$ of registered patients will consult their general practitioner with a rheumatic complaint. ${ }^{8}$ Yet formal teaching at undergraduate level about these complaints is often deficient. In 1971 over a third of medical schools had at best rudimentary undergraduate teaching in rheumatology. ' Although it seemed that rheumatology had come to occupy a slightly larger part in the curriculum, a report on undergraduate education in rheumatology in 1979 highlighted unacceptable variation in the amount and quality of teaching offered in medical schools in the British Isles. ${ }^{10}$ Although almost all schools offered a series of systematic lectures, only $40 \%$ organised a formal course, and the mean time allotted in the curriculum was only about 36 hours. Many doctors currently in general practice have therefore had little or no formal training in dealing with rheumatological conditions, and especially in examination of the musculoskeletal system, even though these comprise a substantial part of their workload.

One of the sources of skill that might be used to remedy deficiencies and provide an update on advances is the rheumatological specialist. This paper concerns the result of an inquiry to consultant rheumatologists about their contribution to the further education of general practitioners.

\section{Methods}

A workshop on the consultant's role in continuing education of general practitioners was sponsored by the Arthritis and Rheumatism Council as part of its educational work. ${ }^{11}$ In preparation for this a questionnaire was sent to all consultant rheumatologists and consultants with an interest in rheumatology in early 1981 . The names of these specialists were derived from the British League Against Rheumatism's manpower register. Consultants were asked about their participation in the teaching of general practitioners in the year 1980.

Inquiries were made about the types of teaching, where this took place, the sponsorship and initiation of the teaching sessions, and the topics taught. The questionnaire distinguished between collective teaching-for example, lectures-and small group teaching (see table I). Respondents were also given the opportunity to comment on present arrangements and to suggest future improvements.

\section{Results}

DATA FROM THE QUESTIONNAIRE

A total of 243 questionnaires were sent out and 203 replies received, giving a response rate of $84 \%$. The data tabulated in this paper come from the 197 adequately completed questionnaires. Altogether $157(80 \%)$ of these consultants had participated in some form of teaching of established general practitioners. One hundred and forty seven had participated in collective teaching sessions and 99 in small group teaching: 89 consultants had done both (table I).

Lectures were the predominant form of collective teaching, comprising $54 \%$ of all such sessions; $88 \%$ of the consultants gave lectures. There seemed to be some uncertainty about what was meant by small group teaching, so 
that data on this are less satisfactory. We gained the impression from some responses that the size of the group rather than the style of teaching was used as the arbiter.

The overall level of drug company sponsorship was considerable, especially for more commercially oriented programmes. Table II gives details of sponsorship as well as about the initiation and venue of the two modes of teaching. The other major sponsors for collective teaching were postgraduate medical centres, which, with drug companies, initiated about half of the collective teaching sessions. General practitioners or general practitioner educators initiated only $10 \%$ of collective teaching, in contrast to $31 \%$ of small group teaching sessions. Collective teaching was most commonly carried out in postgraduate medical centres; small group teaching sessions took place equally commonly in general practitioners' premises.

Table III shows the topics taught. We put the topics into approximate

TABLE 1-Types of teaching of general practitioners undertaken by rheumatologists (figures for numbers of sessions refer to 1980 and are minimum estimates, as some respondents did not state the number of sessions but just indicated that they participated)

\begin{tabular}{|c|c|c|c|c|c|}
\hline & \multirow{2}{*}{$\begin{array}{c}\text { No } \\
\text { of } \\
\text { consultants }\end{array}$} & \multirow{2}{*}{$\begin{array}{c}\text { No } \\
\text { of } \\
\text { sessions }\end{array}$} & \multicolumn{2}{|c|}{ Sessions per consultant } & \multirow{2}{*}{$\begin{array}{l}\text { Proportion of sessions } \\
\text { sponsored by drug } \\
\text { company (\%) }\end{array}$} \\
\hline & & & Median & Range & \\
\hline \multicolumn{6}{|c|}{ Collective teaching sessions } \\
\hline $\begin{array}{l}\text { Lecturet } \\
\text { Talkキ: }\end{array}$ & 129 & 562 & $2 \cdot 8$ & $1-26$ & 40 \\
\hline $\begin{array}{l}\text { Non-commercial } \\
\text { Commercial-educational } \\
\text { Promotional }\end{array}$ & $\begin{array}{l}25 \\
59 \\
39\end{array}$ & $\begin{array}{r}54 \\
134 \\
57\end{array}$ & $\begin{array}{l}1.8 \\
1.6 \\
1.2\end{array}$ & $\begin{array}{l}1-9 \\
1-8 \\
1-6\end{array}$ & $\begin{array}{l}28 \\
84 \\
83\end{array}$ \\
\hline $\begin{array}{l}\text { Symposium S: } \\
\text { Rheumatological } \\
\text { Mixed } \\
\text { Question-answer\| }\end{array}$ & $\begin{array}{l}77 \\
29 \\
22\end{array}$ & $\begin{array}{r}154 \\
50 \\
35\end{array}$ & $\begin{array}{l}1.4 \\
1.6 \\
1 \cdot 2\end{array}$ & $\begin{array}{l}1-12 \\
1-4 \\
1-5\end{array}$ & $\begin{array}{l}46 \\
40 \\
60\end{array}$ \\
\hline All collective teaching & 147 & 1046 & $4 \cdot 5$ & $1-33$ & \\
\hline \multicolumn{6}{|c|}{ Small group teaching sessions } \\
\hline $\begin{array}{l}\text { Discussion: } \\
\text { As leader } \\
\text { As participant } \\
\text { Teaching consultation } \mid \\
\text { General practitioner attachment }{ }^{\star \star} \\
\text { Other }\end{array}$ & $\begin{array}{l}54 \\
19 \\
34 \\
33 \\
12\end{array}$ & $\begin{array}{r}160 \\
34 \\
219 \\
305 \\
122\end{array}$ & $\begin{array}{l}1 \cdot 5 \\
1 \cdot 3 \\
2 \cdot 2 \\
3 \cdot 3 \\
1 \cdot 2\end{array}$ & $\begin{array}{l}1-29 \\
1-4 \\
1-60 \\
1-97 \\
1-98\end{array}$ & $\begin{array}{r}11 \\
44 \\
5 \\
0 \\
5\end{array}$ \\
\hline All small group teaching & 99 & 840 & $2 \cdot 5$ & $1-102$ & \\
\hline
\end{tabular}

^Figures for small group sessions are inflated by a few consultants who participated in many teaching consultations or general practitioner attachments.

†Solo performance for $>40$ minutes.

†Speaking in conjunction with audiovisual (film or tape-slide) presentation. Non-commercial-for example, material produced by Arthritis

\$Speaking in conjunction with audiovisual (film or tape-slide) presentation. Non-commercial-for example, material produced by Arthritis and Rheumatism Council. Commercial-educational-sponsorship advertisements but no explicit referen

SSymposium (10-30 minute contributions) in conjunction with other speakers, with either only rheumatological topics or mixed topics including rheumatology in symposium.

||Specific question and answer sessions (perhaps with introduction, but without associated lecture or audiovisual presentation).

TFor example, peripheral clinic, visit to health centre.

$\star \star$ General practitioner attends, for example, department for a limited period, but not as a clinical assistant or hospital practitioner.

TABLE II-Details of sponsorship, initiation, and venue of collective and small group teaching sessions (figures are numbers (\%) of sessions ${ }^{\star}$ )

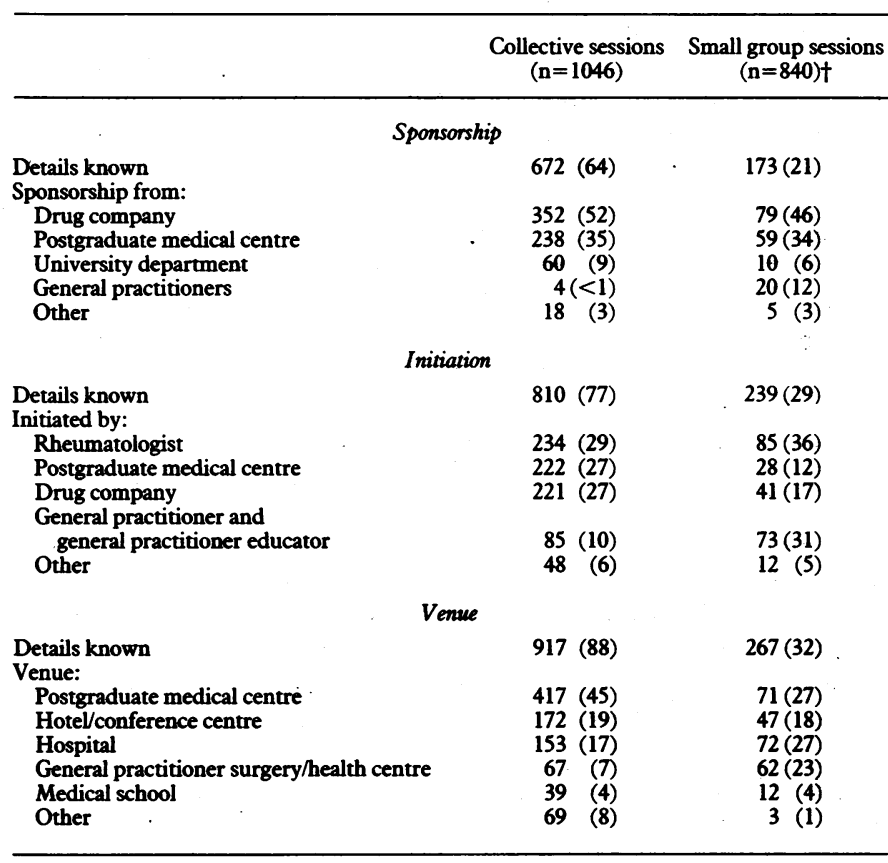

^Figures are minimum estimates, as some respondents did not state number of sessions. tThe lower proportion of small group sessions for which details are known is due to high
number of clinical sessions being counted in overall number of sessions and for which these questions were not completed. diagnostic classes so that they could be compared with the frequency of different types of rheumatic problem presenting in general practice. Arthritis was explicitly mentioned in $44 \%$ of all topics listed, although only $20 \%$ of the patients presenting to a general practitioner in the course of a year with musculoskeletal complaints are likely to have arthritis. Back pain, rheumatism, and sprains and strains were underrepresented in terms of the topics taught, although this comparison takes no account of the clinical importance of the different conditions.

\section{RESPONSES TO OPEN ENDED QUESTIONS}

Altogether 88 (45\%) respondents answered the open ended questions. On the whole they thought that there was a great need for more postgraduate education of general practitioners. Though ideally all undergraduates should receive adequate training, a lot of respondents thought that vocational training schemes for aspiring general practitioners were the best way for the future. The respondents had experienced various educational strategies and chose to comment on them; there were four broad categories.

Extension of education via formal teaching (in postgraduate medical centres): rheumatology should be on the programme at postgraduate medical centres, with closer liaison between hospitals and general practitioner coordinators (six consultants).

Small group teaching (preferably in a general practitioner's premises): this might be based on case material, particularly when general practitioners presented their own cases or when short courses in practical aspects used real patients ( 18 consultants).

Apprenticeship schemes (clinical attachments, clinical assistantships) have an educational role as well as helping with the workload, though respondents noted that the quality of the training given under these schemes would depend on the provisions made for instruction. Short term clinical attachments of general practitioners, perhaps for one or two sessions a week for three to six months, directed towards acquisition of practical manage- 
ment skills such as soft tissue injection, were also commended (14 consultants).

Interchange between general practitioners and consultants about their shared cases: educational opportunities can be provided by fostering more contact between general practitioners and consultants over their shared cases, including telephone consultations. To quote one consultant: "Every contact with a general practitioner, whether face to face, telephone conversation, or by letter, offers an educational situation and I try to use it as such" (12 consultants).

A majority sentiment was that teaching should be directed towards the types of problems likely to be encountered in general practice, with an emphasis on the management of simple but common problems and the acquisition of skills. This is in direct contrast to what was actually taught (table III).

TABLE III-Topics taught by consultants (this refers mainly to collective teaching sessions and therefore underestimates contributions of topics taught in small group sessions)

\begin{tabular}{|c|c|c|c|}
\hline Rheumatic problem & $\begin{array}{l}\text { No of } \\
\text { mentions } \\
\text { of topic }{ }^{\star}\end{array}$ & $\begin{array}{l}\text { No of mentions as } \\
\% \text { of all topics } \\
\text { mentioned }\end{array}$ & $\begin{array}{l}\% \text { Of patients presenting } \\
\text { to general practitioner } \\
\text { during one year }{ }^{20}\end{array}$ \\
\hline Arthritis & 196 & 44 & 20 \\
\hline Rheumatoid arthritis & 77 & 17 & 3 \\
\hline Osteoarthritist & 24 & 5 & 12 \\
\hline Goutt & 23 & 5 & 1 \\
\hline Unspecifiedf & 72 & 16 & 4 \\
\hline Back & 56 & 13 & 22 \\
\hline Back pain & 32 & 7 & 18 \\
\hline Ankylosing spondylitis and & & 3 & \\
\hline Otherf & $\begin{array}{r}15 \\
9\end{array}$ & $\begin{array}{l}3 \\
2\end{array}$ & 4 \\
\hline Rheumatism & 60 & 13 & 23 \\
\hline Necks, shoulders, and arm & 19 & 4 & 6 \\
\hline Knees and feet & 4 & 1 & 3 \\
\hline Other joint pain & 5 & 1 & 3 \\
\hline Soft tissue rheumatism & 8 & 2 & $11 \|$ \\
\hline Polymyalgia rheumatica & 11 & 2 & \\
\hline Injection techniques & 13 & 3 & \\
\hline Sprains and strains & 17 & 4 & 20 \\
\hline Injury and sports injury & 5 & 1 . & \\
\hline Injection techniques & 12 & 3 & \\
\hline Other & 118 & 26 & 15 \\
\hline Other musculoskeletal & & & \\
\hline $\begin{array}{l}\text { (connective tissue disease, } \\
\text { Paget's disease, etc) }\end{array}$ & 8 & 2 & 8 \\
\hline Unspecified $\star \star$ & 110 & 25 & $7 \mathrm{Ht}$ \\
\hline Total & 447 & & \\
\hline
\end{tabular}

*This does not take account of the number of times a given topic was taught.

†Twelve mentions of metabolic or crystal arthropathy divided between osteoarthritis and gout.

$\ddagger$ Many likely to be mainly rheumatoid arthritis.

Includes three mentions of manipulation, one of osteopathy, and one of chiropractic.

Non-articular rheumatism.

IT wenty five mentions of injection techniques divided between rheumatism and sprains and strains.

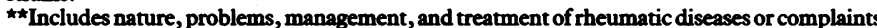
in general practice. A sizable proportion were mainly concerned with arthritis (only five mentions of assessment of locomotor problems and examination of joints).

HIll defined.

Negative comments were made by 28 consultants (32\%). These were to the effect that the general practitioners who need education do not attend ("most teaching is preaching to the converted"); there is a lack of interest among established general practitioners (although a few consultants remarked that general practitioners in their area seemed to be keen); general practitioners are offered too much postgraduate education; general practitioners have to be selective ("drug companies have saturated the desire for teaching in rheumatology"); and, finally, a lot of education taking place in hospitals for hospital staff is open to general practitioners, but they rarely attend.

The consultants volunteering comments in this study had mixed thoughts about the role of the drug companies. The support of these companies was seen as essential by some and undesirable by others, though respondents recognised that it was sometimes inevitable to achieve a suitable level of hospitality. As one consultant commented: "General practitioners are conditioned to receiving rewards in return for education." Incentives were seen in terms of cash or food. Apart from rewards for general practitioners, respondents acknowledged that consultants might require rewards to be prepared to teach.

Various other material constraints on participation in teaching became evident from the questionnaire. Some consultants had little time for such activities, particularly when junior staff were not available. A high service commitment was cited as an obstacle by many, and research commitments by some. Geographical constraints gave rise to difficulties in getting to general practitioners in districts covering large areas, and also for general practitioners to get to consultants. Rural areas, in particular, were also likely to have consultants without junior staff and a particularly high caseload from a large catchment area.

\section{Discussion}

This study was concerned only with continuing rheumatological education in which consultant rheumatologists participated directly. We were not able to take into account the large amount of educational material and opportunities provided by postgraduate medical centres and pharmaceutical companies, nor the sessions organised by general practitioners themselves or under the auspices of the Royal College of General Practitioners.

After private reading, formal lectures at a postgraduate medical centre are the most generally pursued method of continuing education for general practitioners. ${ }^{6}$ Most lecturers at such centres are medical specialists, ${ }^{12}$ and this is reflected in the experience of the consultant rheumatologists in this survey. The topics taught tended to reflect hospital and personal interests. This again is in line with the finding that formal lectures tend to focus on transferring available knowledge rather than on working on problems in general practice that require an educational solution..$^{12} \mathrm{~A}$ survey of recently appointed consultants (all specialties) showed that most consultants have little knowledge of the true content of most general practitioners' work and also that few consultants thought it appropriate that general practitioners should learn to give intra-articular steroid injections. ${ }^{13}$ Similar reservations were apparent among some of our respondents.

Small group teaching is now widely accepted as perhaps the most valuable method of achieving behavioural change in general practice, ${ }^{1}$ and evaluation of such courses in rheumatology has shown changes in the performance of participants in diagnosing and treating rheumatic disorders. ${ }^{14} 15$ There was some indication that more was learnt from general practitioner than from consultant tutors. ${ }^{14} 16$ Those consultants in our survey who had taken part thought that they had benefited; perhaps it will take time to educate a cadre of consultant rheumatologists who will be able to teach effectively under such circumstances. Griffen advocated experimentation in education with general practitioner tutors supported by consultant skilli6; this would reflect the shared care of rheumatic disease by general practitioners and consultants.

All methods of teaching that provide extensive teacher-student contact are time consuming for the teacher. In addition, small group teaching and other structured programmes require a considerable investment in planning on the part of the instructors. ${ }^{14}$ It is difficult to gauge whether such aspects acted as a deterrent to our respondents or whether their lesser participation in such activities reflected lack of opportunity to take part, for whatever reason. That many consultants, while advocating small group, practically oriented sessions, nevertheless gave formal lectures in postgraduate medical centres might well reflect institutional arrangements. Lecturing is an entrenched method of teaching, and "even if conclusive evidence were obtained that lectures have a null effect on the audience, it would be unlikely to make lecturers abandon their traditional mode of teaching." 12

Some respondents considered that contact between a consultant and local general practitioners was an important educational opportunity. This raises the more general question of the role of the consultant vis à vis the general practitioner. In a survey of recently qualified consultants both consultants and general practitioners agreed that consultants followed up too many outpatients. ${ }^{13}$ In a system in which general practitioners were responsible for the day to day management of patients with arthritis the job of the specialist would be defining a plan for continuing care and suggesting to the general practitioners the nature of the monitoring required and the criteria for rereferral in each case. ${ }^{3}$ Consultants would have to accept more responsibility for appropriate continuing education of general practitioners in their catchment area and for assisting in 
designs for follow up in general practice geared to local and individual needs. ${ }^{3}$

There remains the question of the effectiveness of continuing education in changing the way that general practitioners assess and treat their patients with rheumatic complaints. Evaluation of schemes in both the United Kingdom ${ }^{14}{ }^{17}$ and the United States ${ }^{1819}$ showed that the knowledge, management skills, and referral patterns of such physicians can be improved and that this may lead to better outcomes for patients. ${ }^{19}$. The work of Stross in the United States has highlighted the role of "educationally influential physicians,". key people who are frequently consulted by their peers. Here perhaps is a further role for the consultant, either in person or as an agent, in developing key general practitioners who are influential among their fellow professionals.

Consultant rheumatologists represent a valuable resource of knowledge and experience in the treatment and management of rheumatic disorders and could thus help other people concerned with these disorders. A future challenge is to make better use of the consultants' specialist knowledge in the continuing education of general practitioners, at the same time providing the consultants with the opportunity to learn more about rheumatological problems as they are encountered in general practice.

This study showed that although a high proportion of consultant rheumatologists participated in continuing education of general practitioners, the types of teaching thought most desirable by consultants (that is, with close contact between consultant and general practitioner) and what should be taught (practical management) bore little resemblance to the predominant modes of teaching used. What was actually taught reflected the type of caseload more likely to be encountered in a hospital setting, with the emphasis on inflammatory arthropathies rather than the pattern of diagnoses made in general practice. The workshop organised by the Arthritis and Rheumatism Council initiated a discussion between specialists in rheumatology and representatives of the Royal College of General Practitioners; this is continuing and should bear fruit in terms of the continuing education and mutual understanding of both parties.
We thank Professor Philip Wood for his support and valuable comments on this project and the preparation of this paper, and Mrs Ann Papageorgiou for bibliographical help.

\section{References}

1 Donald AG. Continuing learning in practice project (CLIPP). foumal of the Royal College of General Practitioners 1984;34:242-5.

2 Scottish Council for Postgraduate Medical Education (SCPME). Maintaining standards in general practice. Edinburgh: SCPME, 1981.

3 Hart JT. Specialization in general practice. Journal of the Royal College of General Practitioners 1980;30:216-9.

4 Reedy BLEC, Gregson BA, Williams M. General practitioners and postgraduate education in the northem region. London: Royal College of General Practitioners, 1979. (Occasional paper 9.)

5 Wood J, Byrne PS. Section 63 activities. London: Royal College of General Practitioners, 1980. (Occasional paper 11.)

6 Pickup AJ, Mee LG, Hedley AJ. The general practitioner and continuing education. fournal of the Royal College of General Practitioners 1983;33:486-90.

7 Hobbs R. It's come a long way. Br Med f 1984;288:885-7.

8 Wood PHN, Badley EM. Epidemiology of locomotor disorders in general practice. In: Jayson MIV, Million R, eds. Locomotor disability in general practice. Oxford: Oxford University Press, 1983:3-29.

9 Wood PHN, Benn RT. Undergraduate training in rheumatology in the United Kingdom. British foumal of Medical Education 1972;6:325-32.

10 Wood PHN, Badley EM, eds. People with arthritis deseroe well-trained doctors: report of a workshop organized by the Arthritis and Rheumatism Council. London: Arthritis and Rheumatism Council, 1979

11 Wright $\mathrm{V}$. The consultant rheumatologist and postgraduate education. $\mathrm{Br} \mathrm{Med}$ J 1983;287: $1158-9$.

12 Wood J, Byrne PS. Lecturing to general practitioners. Joumal of the Royal College of General Practitioners 1979;29:241-5.

13 Whitfield MJ. What do consultants think of general practice? foumal of the Royal College of General Practitioners 1980;30:228-9.

14 Griffen GA, Kaneti Barry SM. Muscle and joint pain: design and evaluation of courses for general practitioners. Journal of the Royal College of General Practitioners 1981;31:661-8.

15 Golding DN. Postgraduate education in rheumatology: who should teach what and to whom? $\mathcal{J} R$ Soc Med 1982;75:985-6.

16 Griffen GA. Continuing education in rheumatology. $\mathcal{F} R$ Soc Med 1982;75:985-6.

17 Grahame R, Gibson T, Dale E, et al. An evaluated programme of rheumatology training for general practitioners. Br $\mathcal{Y}$ R heumatol 1986;25:7-12.

18 Stross JK, Bole GG. Evaluation of an educational program for primary care practitioners, on the Stross JK, Bole GG. Evaluation of an educational program for pri
management of osteo-arthritis. Arthritis Rheum 1985;28:108-11.

19 Stross JK, Schumacher HR, Weisman MH, Spalding DM. Continuing medical education: changing behaviour and improving outcomes. Arthritis Rheum 1985;28:1163-7.

20 Royal College of General Practitioners. Second national mobility study. London: Office of Population Censuses and Surveys, 1974.

(Accepted 7 October 1986)

\title{
Prescribing in Pregnancy
}

\section{Treatment of asthma}

\author{
K FAN CHUNG， PETER J BARNES
}

About $1 \%$ of pregnant women suffer from active asthma..$^{1-3}$ Current evidence suggests that uncontrolled asthma may lead to maternal hypoxaemia with potentially grave consequences for the fetus. Asthma in pregnancy should therefore be treated promptly and appropriately to reduce perinatal mortality and morbidity. As in non-obstetric practice, management of pregnant women with

\footnotetext{
Department of Clinical Pharmacology, Cardiothoracic Institute, Brompton Hospital, London SW3 6HP

K FAN CHUNG, MD, MRCP, clinical lecturer

PETER J BARNES, DM, FRCP, professor of clinical pharmacology

Correspondence to: Dr Chung.

This series is edited by Dr PC Rubin.
}

asthma aims at preventing recurrent attacks of wheezing, status asthmaticus, and respiratory failure. Drugs that are teratogenic or detrimental to the fetus should obviously be avoided.

\section{Asthma and pregnancy \\ PULMONARY FUNCTION DURING PREGNANCY}

The enlarging fetus and the increased concentration of circulating hormones, such as progesterone and cortisol, contribute to several changes in pulmonary function in pregnancy. ${ }^{47}$ Reductions in residual volume and functional residual capacity occur before appreciable enlargement of the uterus. Spirometric tests of airway function such as forced expiratory volume in one second remain unchanged. Throughout pregnancy there is a progressive rise in 